\title{
Analisis Kesulitan Belajar Mahasiswa Teknik Informatika Pada Mata Kuliah Aljabar Linier
}

\author{
Ayu Ismi Hanifah ${ }^{1}$, Nur Qomariyah Nawafilah ${ }^{2}$ \\ ${ }^{1,2}$ Fakultas Teknik,Universitas Islam Lamongan \\ e-mail: ${ }^{1}$ ayuismihanifah@gmail.com, ${ }^{2}$ nq.nawafil@yahoo.com
}

\begin{abstract}
Linear Algebra is a course that must be taken by Informatics Engineering students. Linear Algebra has an important role in providing competences in the form of basic knowledge and abilities to formulate problems in mathematical form that will be solved using computation.This study aimed to describe the factors that caused learning difficulties of Informatics Engineering students in the Linear Algebra subject. This research was a qualitative descriptive study to describe the factors that caused learning difficulties in solving linear algebra problems. Data mining methods in this study were using data results of solving four linear algebra problems and interview.Samples were taken from students who had errors in solving problems. The results of this study indicated that the factors caused students to experience learning difficulties when taking linear algebra subject were lack of student interest in Linear Algebra leaning material, low basic Linear Algebra skills, and lack of ability to apply Linear Algebra concepts in solving problems. The followings were indicators of errors that affected student learning difficulties in problems solving when they were taking linear algebra subject, including: (1) Inadequate in understanding linear algebra problems, (2) Inaccurate in the operation of algebraic and integer numbers,(3) lack of ability to understand the concept of elementary number operations, and (4) lack of students' logical ability in arranging problem solving methods.
\end{abstract}

Keyword: linear algebra, learning difficulties, matrix.

\begin{abstract}
Abstrak. Aljabar Linier merupakan mata kuliah yang harus diambil oleh mahasiswa Teknik Informatika. Aljabar Linier mempunyai peran penting dalam memberikan kompetensi berupa pengetahuan dan kemampuan dasar guna memformulasikan permasalahan-permasalahan dalam bentuk matematis yang akan diselesaikan dengan menggunakan komputasi. Penelitian ini bertujuan untuk mendeskripsikan faktor penyebab kesulitan belajar mahasiswa Teknik Informatika pada mata kuliah Aljabar Linier. Penelitian ini merupakan penelitian deskriptif kualitatif dengan upaya mendeskripsikan faktor-faktor penyebab kesulitan mahasiswa dalam menyelesaikan persoalan Aljabar Linier. Sumber data dalam penelitian ini berupa data hasil penyelesaian empat persoalan Aljabar Linier dan data wawancara. Sampel diambil dari mahasiswa yang mengalami kesalahan dalam menyelesaikan soal. Hasil penelitian ini menunjukkan bahwa faktor yang menyebabkan mahasiswa mengalami kesulitan belajar ketika mengikuti mata kuliah Aljabar Linier adalah kurangnya minat belajar mahasiswa pada materi Aljabar Linier, kemampuan dasar Aljabar Linier yang rendah, dan kurangnya kemampuan dalam mengaplikasikan konsep Aljabar Linier dalam menyelesaikan soal. Berikut indikator kesalahan yang mempengaruhi kesulitan belajar mahasiswa dalam mengikuti mata kuliah Aljabar Linier dalam menyelesaikan soal, diantaranya: (1) kurang teliti dalam memahami persoalan Aljabar Linier, (2) kurang teliti dalam pengoperasian bilangan aljabar maupun bilangan bulat, (3) kurang mampu dalam konsep operasi bilangan elementer, dan (4) kurangnya kemampuan logika mahasiswa dalam menyusun cara penyelesaian soal.
\end{abstract}

Kata Kunci: Aljabar Linier, kesulitan belajar, matrik 


\section{PENDAHULUAN}

Kurikulum program studi Teknik Informatika di Universitas Islam Lamongan (UNISLA) memiliki mata kuliah wajib yang harus diambil. Adapun Mata Kuliah Keilmuan dan Keterampilan (MKK) yang berkaitan dengan matematika diantaranya yaitu Kalkulus, Matematika Diskrit, Statistika, dan Aljabar Linier. Menurut Djafar, dkk (2019), Aljabar Linier merupakan mata kuliah wajib yang harus diambil oleh mahasiswa dengan tujuan agar mahasiswa mempunyai pemikiran yang lebih logis secara sistematis dan lebih kritis. Selain itu, mata kuliah tersebut juga dibutuhkan sebagai dasar lanjutan mengikuti mata kuliah yang berkaitan dengan pemograman yang ada pada mata kuliah selanjutnya, diantaranya yaitu Manajemen Sains, Bisnis Cerdas, dan Data Mining.

Aljabar Linear memiliki peran penting dalam memberikan kompetensi berupa pengetahuan dan kemampuan dasar guna memformulasikan permasalahan-permasalahan dalam bentuk matematis yang akan diselesaikan dengan menggunakan komputasi. Untuk mata kuliah Aljabar Linier pada program studi Teknik Informatika di UNISLA diberikan kepada mahasiswa semester 2 dengan bobot 3 sks.

Adapun penelitian-penelitian yang telah mengkaji tentang analisis kesulitan, diantaranya yaitu Wasito dan Fandi (2018) yang telah meneliti penyebab kesulitan belajar mahasiswa Manajemen Informatika dalam pembelajaran konstruktivis mata kuliah aljabar. Hasil dari penelitian yang didapat yaitu kurang percaya dirinya mahasiswa dalam mengkomunikasi ide atau pendapat, modul Aljabar Linier yang masih belum mengarah pada penemuan konsep, mahasiswa belum bisa untuk menganalisis masalah yang baru ditemui, dan faktor yang paling utama adalah mahasiswa belum terbiasa dengan pembelajaran yang menekankan untuk mengkonstruksi konsep sendiri.

Dalam penelitian Djafar, dkk (2019) juga diungkapkan bahwa penyebab kesulitan mahasiswa Manajemen Informatika belajar aljabar adalah kurang terampil siswa dalam mengoperasikan bilangan bulat, siswa kurang teliti, kemampuan logika siswa masih kurang dalam mengerjakan operasi baris dasar, dan adanya keraguan siswa dalam menyelesaikan masalah.

Selain penelitian yang telah disebutkan, ada pula penelitian yang memaparkan penyebab dan solusi mengatasi kesulitan belajar mahasiswa diantaranya yaitu Wati, dkk(2018) yang mengkaji tentang penyebab kesulitan belajar siswa dikarenakan kurangnya pemahaman konsep dan cara guru mengajar. Dalam penelitian yang dipaparkan, TPACK adalah cara untuk memahami hubungan kompleks antara pengajaran dan konten yang diajarkan melalui pendekatan pengajaran khusus didukung perangkat teknologi.

Hasil TPACK pada penelitian menunjukkan masih rendah artinya kemampuan TPACK guru dalam pembelajaran persamaan linier masih perlu ditingkatkan. Dalam hal ini perangkat PowerPoint merupakan kemampuan teknologi modal TCK yang dapat mengatasi kesulitan belajar siswayang dapat digunakan oleh guru. 
Terlepas adanya penelitan yang telah dipaparkan, alasan utama penelitian ini dilakukan terkait dengan pengalaman peneliti yang telah mengajar mata kuliah Aljabar Linier selama tiga tahun. Dari pengalaman peneliti, masih banyak mahasiswa yang kesulitan ketika mengikuti mata kuliah Aljabar. Kesulitan mahasiswa dilihat dari kesalahan mahasiswa ketika menyelesaikan persoalan yang diberikan peneliti. Selain itu, peneliti juga menganalisis faktor-faktor yang mempengaruhi kesulitan mahasiswa dalam menempuh mata kuliah Aljabar Linier.

Penelitian ini merupakan penelitian studi kasus. Rumusan masalah dalam penelitian ini adalah analisis kesulitan belajar mahasiswa dilihat dari faktor-faktor penyebab kesulitan ketika memperoleh mata kuliah Aljabar. Tujuan dari penelitian ini adalah mendeskripsikan faktor penyebab kesulitan belajar mahasiswa. Kesulitan belajar dalam penelitian ini juga dilihat dari indikatorindikator yang mempengaruhi kesulitan belajar mahasiswa yang muncul pada kesalahan mahasiswa ketika menyelesaikan persoalan Aljabar Linier.

Persoalan Aljabar Linier yang diberikan dalam penelitian ini yaitu persoalan yang berkaitan dengan matriks. Dengan adanya penelitian ini diharapkan dapat membantu pendidik menganalisis kesulitan belajar mahasiswa agar mahasiswa lebih dapat memahami mata kuliah Aljabar Linier yang diberikan dan dapat menyelesaikan persoalan dengan benar dan tepat.

\section{METODE}

Penelitian ini mengenai studi kasus membahas tentang kesulitan belajar mahasiswa pada mata kuliah Aljabar Linier, khususnya pada materi Matriks. Berdasarkan tujuan penelitian yang telah dipaparkan maka penelitian ini merupakan penelitian deskriptif kualitatif. Penelitian deskriptif menggambarkan mengenai apa adanya keterkaitan suatu variabel, gejala atau keadaan (Arikunto, 2010:21). Sedangkan penelitian kualitatif merupakan penelitian yang dilakukan guna mendeskripsikan dan menganalisis fenomena, peristiwa, aktivitas sosial, sikap, kepercayaan, persepsi, pemikiran orang secara individual maupun kelompok (Sukmadinata, 2009:60).

Pada prodi Teknik Informatika (TI) Universitas Islam Lamongan semester Genap 2020/2021 terdapat 3 kelas. Dalam penelitan ini, subjek yang dipilih adalah 3 dari 40 mahasiswa yang diambil dari salah satu kelas TI. Ketiga mahasiswa ini sedang menempuh mata kuliah Aljabar Linier, lebih tepatnya telah menempuh materi Matriks. Selain itu, subjek yang dipilih adalah subjek yang mengalami kesalahan dalam menyelesaikan persoalan Matriks yang diberikan sehingga peneliti dapat menganalisis kesulitan-kesulitan yang dirasakan subjek tersebut ketika belajar Aljabar Linier.

Sumber data dalam penelitan ini berupa data tertulis dan hasil dokumentasi. Untuk prosedur pengumpulan data, sumber data tertulis diperoleh dari data hasil jawaban mahasiswa sehingga mendapatkan beberapa 
indikator kesulitan mahasiswa yang menyebabkan adanya kesalahan ketika menyelesaikan soal. Dalam penelitian ini, mahasiswa diberikan empat soal yang berkaitan dengan materi Matriks.

Hasil analisis lembar jawaban mahasiswa dalam menyelesaikan empat soal yang berikan dikelompokkan menjadi lima kesalahan, diantaranya yaitu: (a) kesalahan konsep; (b) kesalahan keterampilan aljabar dan bilangan; (c) kesalahan memahami soal; (d) tidak menjawab soal; dan (e) tidak menemui kesulitan.

Dari lima kelompok kesalahan yang dipaparkan, peneliti mengidentifikasi sebagai berikut. Kesalahan konsep yaitu kesalahan mahasiswa kurang memahami konsep yang ada materi yang digunakan dalam menyelesaikan soal yang diberikan. Kesalahan keterampilan aljabar dan bilangan bulat yaitu mahasiswa mengalami kekeliruan dalam mengoperasikan bentuk aljabar maupun operasi bilangan. Kesalahan memahami soal yaitu kondisi dimana mahasiswa mengalami kesalahan mengenai maksud dari pertanyaan dari soal yang diberikan. Tidak menjawab soal yaitu mahasiswa tidak mengisi jawaban dari soal yang ditanyakan. Tidak menemui kesalahan yaitu mahasiswa dapat menyelesaikan soal dan menjawab soal tersebut dengan tepat.

Berikut paparan keempat soal matriks yang diberikan peneliti, diantaranya: 1) mencari solusi dari sistem persamaan 3 variabel dengan menggunakan Operasi Baris Elementer (OBE), 2) mencari invers dari matriks ordo $3 \times 3$ dengan menggunakan
OBE, 3) menunjukkan salah satu sifat determinan matriks dengan mengoperasikan matriks yang telah diberikan, dan 4) mencari nilai entri matriks yang diketahui determinannya.

Selain data hasil jawaban penyelesaian soal, peneliti juga melakukan wawancara kepada subjek yang telah dipilih sebelumnya. Dalam penelitian ini, mahasiswa sudah mendapatkan mata kuliah Aljabar Linier selama 5 pertemuan. Wawancara ini dilakukan setelah mahasiswa menyelesaikan soal yang telah diberikan. Dalam wawancara ini peneliti berpedoman pada angket wawancara yang dapat dilihat pada Tabel di bawah ini.

Tabel 1 Angket Wawancara

\begin{tabular}{|c|c|c|}
\hline No. & Pertanyaan & Jawaban \\
\hline 1. & $\begin{array}{l}\text { Apakah mahasiswa siap } \\
\text { dalam memulai belajar } \\
\text { aljabar linier? }\end{array}$ & \\
\hline 2. & $\begin{array}{l}\text { Bagaimana konsep dasar } \\
\text { aljabar matematika yang } \\
\text { dimiliki mahasiswa? }\end{array}$ & \\
\hline 3. & $\begin{array}{l}\text { Bagaimana antusias } \\
\text { mahasiswa ketika belajar } \\
\text { aljabar linier? }\end{array}$ & \\
\hline 4. & $\begin{array}{l}\text { Apakah mahasiswa dapat } \\
\text { menyelesaikan soal yang } \\
\text { diberikan? }\end{array}$ & \\
\hline 5. & $\begin{array}{l}\text { Bagaimana keterampilan } \\
\text { mahasiswa dalam } \\
\text { menyelesaikan soal yang } \\
\text { diberikan? }\end{array}$ & \\
\hline 6. & $\begin{array}{l}\text { Bagaimana kemampuan } \\
\text { logika mahasiswa dalam } \\
\text { menyelesaikan soal yang } \\
\text { diberikan? }\end{array}$ & \\
\hline 7. & $\begin{array}{l}\text { Sejauh mana konsep yang } \\
\text { digunakan mahasiswa } \\
\text { untuk menyelesaikan soal } \\
\text { yang diberikan? }\end{array}$ & \\
\hline 8. & $\begin{array}{l}\text { Bagaimana minat } \\
\text { mahasiswa pada mata } \\
\text { kuliah aljabar linier? }\end{array}$ & \\
\hline
\end{tabular}




\section{HASIL DAN PEMBAHASAN}

\section{Hasil Lembar Jawaban Subjek 1 (S1) Dalam Menyelesaikan Soal}

Dari hasil lembar jawaban S1, cara menyelesaikan soal tersebut dapat dikategorikan ke dalam lima kelompok jenis kesalahan yang telah dikemukakan sebelumnya. Berikut hasil pengelompokkan dapat dilihat di Tabel 2.

Tabel 2 Jenis Kesalahan Menjawab Soal pada Lembar Jawaban S1

\begin{tabular}{lcccc}
\hline \multicolumn{5}{c}{ Subjek 1 } \\
\hline Soal No. & 1 & 2 & 3 & 4 \\
Jenis Kesalahan & (b) & (b),(c) & (a),(b) & (b) \\
\hline
\end{tabular}

Dari Tabel 2 dapat dilihat bahwa kesalahan yang terjadi ketika S1 menyelesaikan soal mencakup kesalahan konsep, kesalahan keterampilan aljabar dan bilangan, dan kesalahan memahami soal. Dari jawaban S1 dalam menyelesaikan soal No 1 dapat dilihat bahwa sebenarnya S1 paham dengan yang ditanyakan dan paham dengan konsep cara OBE namun ketika mengoperasikan terjadi kesalahan. Sehingga jawaban akhir dari soal No 1 menjadi salah.

Untuk penyelesaian soal No 2, S1 menyelesaikannya kurang tepat karena kurang memahami maksud dari soal yang ditanyakan. S1 mencari invers matriks menggunakan Adjoin bukan menggunakan OBE. Selain itu, ketika menyelesaikan dengan menggunakan Adjoin, S1 kurang teliti dalam mengoperasikan bilangan sehingga mengakibatkan jawaban salah.

Jawaban soal no 3, langkah awal S1 ketika menyelesaikan soal No 3 sudah benar yaitu mencari hasil pengoperasian $\operatorname{det}(\mathrm{A}) \operatorname{dan}$ $\operatorname{det}(\mathrm{B})$, namun kurang teliti ketika mengoperasikan sehingga mengalami kesalahan. Selain itu, $\operatorname{det}(\mathrm{AB})$ dituliskan langsung perkalian dari hasil yang dipeoleh sebelumnya bukan mengalikan kedua matriks terlebih dahulu kemudian dicari determinannya.

Dari penyelesaian tersebut terlihat bahwa konsep dasar yang dimiliki S1 masih kurang. Untuk jawaban soal No 4, pemahaman soal dan konsep yang digunakan sudah benar namun S1 mengalami kesalahan ketika mengoperasikan bentuk aljabar yang mengakibatkan jawaban No 4 kurang tepat.

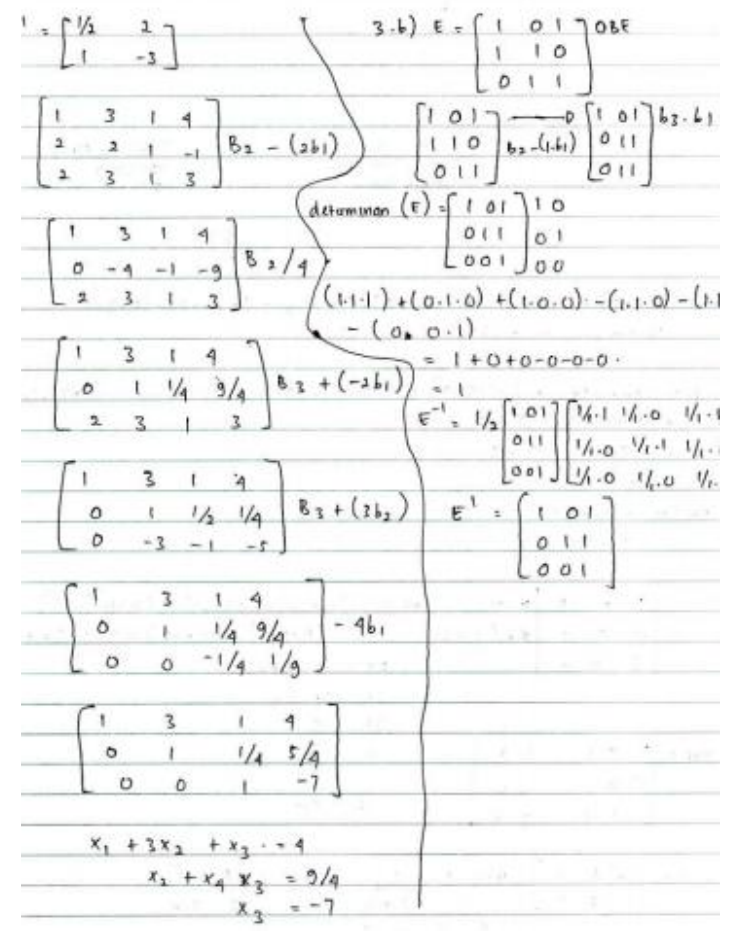

Gambar 1 Hasil Jawaban S1 pada Soal No 1 dan No 2 


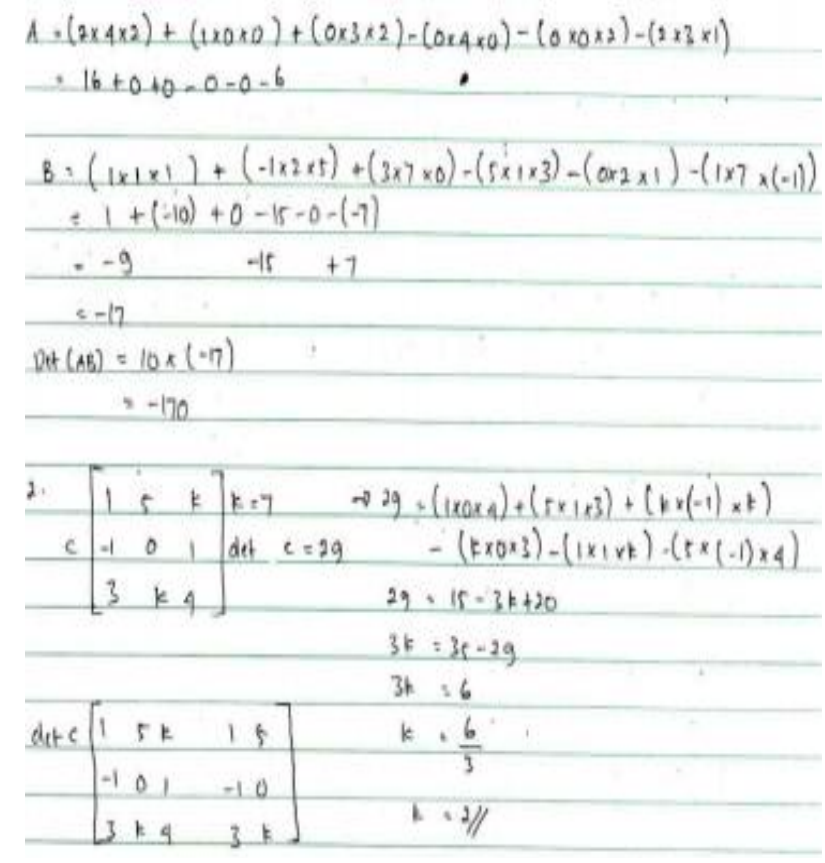

Gambar 2 Hasil Jawaban S1 pada Soal No 3 dan No 4

\section{Hasil Lembar Jawaban Subjek 2 (S2) Dalam Menyelesaikan Soal}

Hasil lembar jawaban S2 dalam menyelesaikan keempat soal berkaitan dengan kelima jenis kesalahan yang telah dipaparkan dapat dilihat pada Tabel 3 berikut.

Tabel 3 Jenis Kesalahan Menjawab Soal pada Lembar Jawaban S2

\begin{tabular}{lcccc}
\hline \multicolumn{5}{c}{ Subjek 2 } \\
\hline Soal No. & 1 & 2 & 3 & 4 \\
Jenis Kesalahan & (a) & (a),(c) & (a),(b) & (a),(d) \\
\hline
\end{tabular}

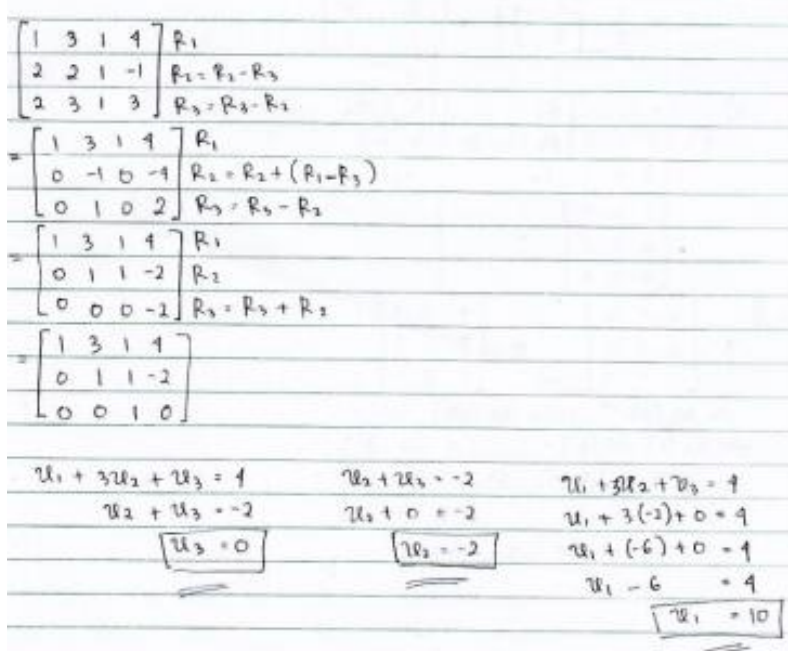

Gambar 3 Hasil Jawaban S2 pada Soal No 1

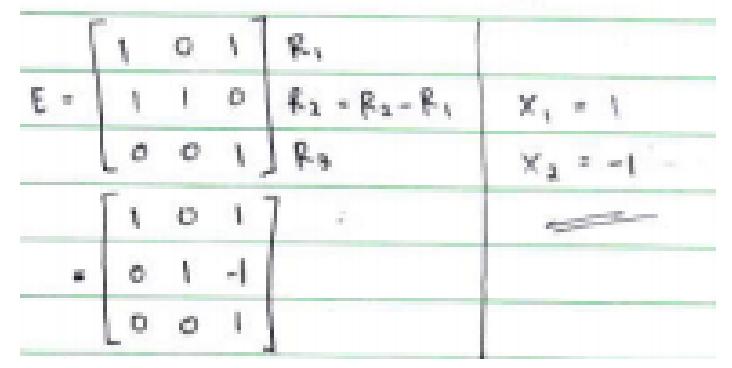

Gambar 4 Hasil Jawaban S2 pada Soal No 2

Dari Tabel 3 terlihat bahwa S2 mengalami beberapa kesalahan diantaranya yaitu kesalahan konsep, kesalahan keterampilan aljabar dan bilangan, dan kesalahan memahami soal, dan S2 tidak menjawab soal yang ditanyakan. Untuk jawaban soal No 1 dapat dilihat bahwa pemahaman konsep OBE oleh S2 masih kurang. Selain itu, kemampuan logika S2 mengenai cara melakukan OBE sangat rendah sehingga untuk mencari sistem penyelesaian kurang tepat.

Dalam menyelesaikan soal no 2, S2 menyelesaikannya kurang tepat karena kurang memahami maksud dari soal yang ditanyakan. S2 mencari solusi dari sistem bukan mencari invers matriks. Terlihat juga bahwa S2 kurang 
paham terhadap konsep materi yang digunakan dalam menyelesaikan soal tersebut sehingga jawaban soal No 2 salah.

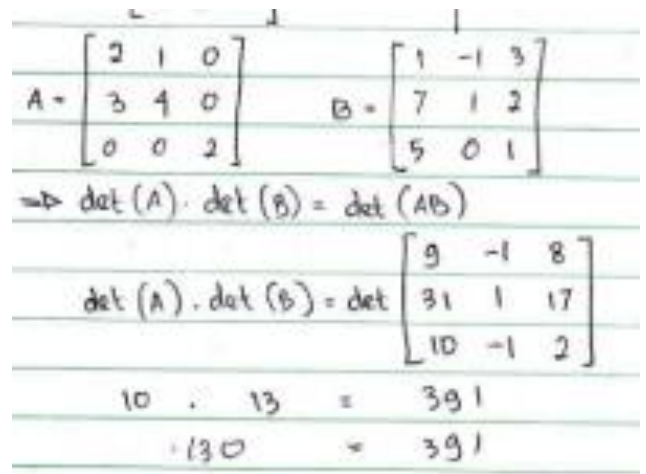

\section{Gambar 5 Hasil Jawaban S2 pada Soal No 3}

Pada jawaban soal No 3 dalam menunjukkan sifat determinan, S2 tidak melakukan operasi bilangan yang terdapat pada soal. Selain itu, dalam mencari det(AB), S2 mengalami kesalahan dalam pengoperasian bilangan bulat sehingga S2 tidak dapat menunjukkan sifat determinan yang ditanyakan. Dari jawaban tersebut terlihat jelas pula bahwa S2 mempunyai konsep dasar yang rendah. Untuk jawaban soal No 4 dapat dilihat bahwa pemahaman S2 pada konsep yang digunakan dalam menyelesaikan soal tersebut sangat kurang. S2 tidak dapat menyelesaikan soal tersebut sehingga stuck dan tidak dapat menjawab soal.

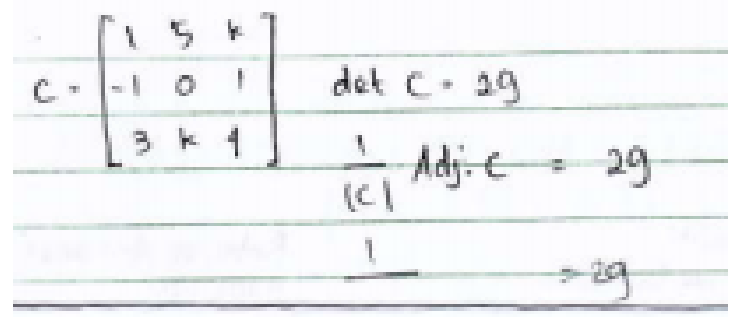

Gambar 6 Hasil Jawaban S2 pada Soal No 4

\section{Hasil Lembar Jawaban Subjek 3 (S3) Dalam Menyelesaikan Soal}

Kesalahan yang tampak pada hasil jawaban S3 pada keempat soal yaitu S3 mengalami kesalahan dalam pengoperasian bilangan. Selain dari kesalahan tersebut, S3 dapat menyelesaikan soal secara benar dan tepat yang dapat dilihat pada Tabel 4 .

\section{Tabel 4 Jenis Kesalahan Menjawab Soal pada Lembar Jawaban S3}

\begin{tabular}{lcccc}
\hline \multicolumn{5}{c}{ Subjek 3 } \\
\hline Soal No. & 1 & 2 & 3 & 4 \\
Jenis Kesalahan & (b) & (b) & (b) & (e) \\
\hline
\end{tabular}

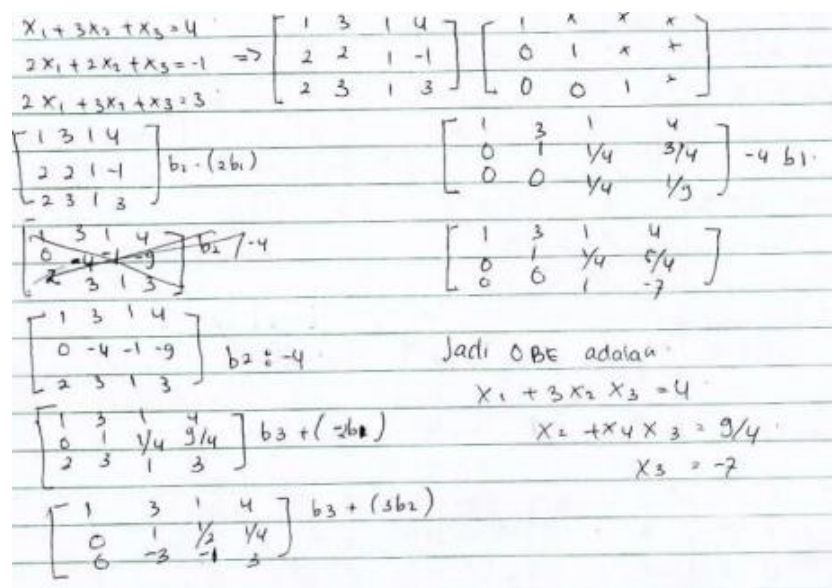

\section{Gambar 7 Hasil Jawaban S3 pada Soal No 1}

Dari jawaban S3 pada soal No 1, 2, dan 3 terlihat bahwa S3 paham dengan yang ditanyakan pada soal. Selain itu, S3 juga paham dengan konsep-konsep yang digunakan untuk menyelesaikan soal tersebut. Langkah yang dilakukan dalam menyelesaikan juga sudah benar. Namun, kesalahan muncul pada proses mengoperasikan bilangan yang menimbulkan jawaban yang didapat menjadi salah. Sedangkan untuk soal No 4, S3 tidak mengalami kesulitan sehingga tidak 
mengalami kesalahan dan dapat menjawab soal dengan benar dan tepat.

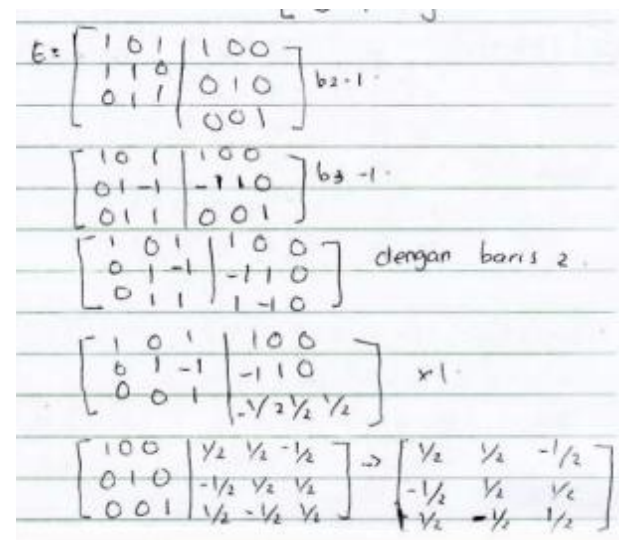

Gambar 8 Hasil Jawaban S3 pada Soal No 2

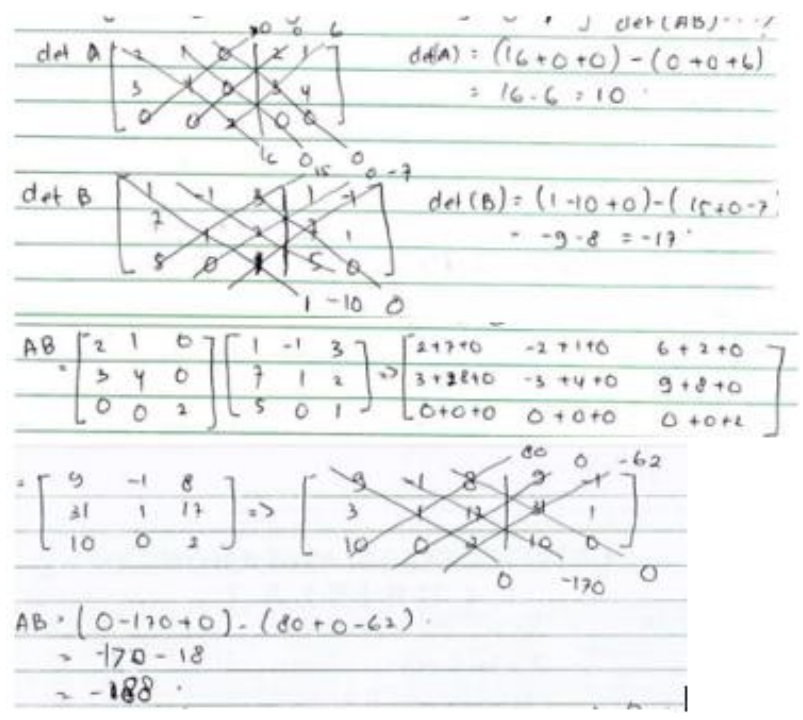

Gambar 9 Hasil Jawaban S3 pada Soal No 3

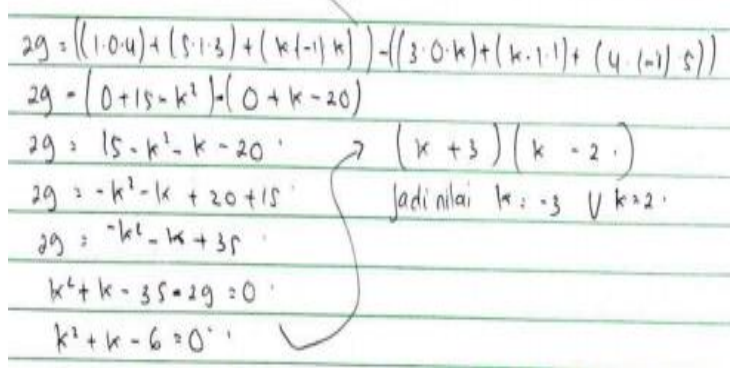

Gambar 10 Hasil Jawaban S3 pada Soal No 4

\section{Hasil Angket Mengenai Kesulitan Mahasiswa Dalam Belajar Aljabar Linier}

Berdasarkan hasil wawancara yang dilakukan pada ketiga subjek, dapat disimpulkan bahwa mahasiswa merasa kurangnya konsep dasar yang dimiliki untuk mengikuti mata kuliah Aljabar Linier. Mahasiswa mengaku lupa dengan materi dasar yang mencakup Aljabar Linier. Selain itu, kurangnya minat belajar mahasiswa pada mata kuliah Aljabar Linier juga mempengaruhi. Hal ini menyebabkan kurang termotivasinya mahasiswa untuk memulai belajar mata kuliah Aljabar Linier sehingga mahasiswa mengalami kesulitan dalam belajar. Selain itu, mahasiswa juga kesulitan dalam pengaplikasian konsep Aljabar Linier dalam menyelesaikan soal.

\section{SIMPULAN (PENUTUP)}

\section{Kesimpulan}

Dari hasil penelitian dan pembahasan yang telah dipaparkan, dapat disimpulkan bahwa faktor-faktor yang menyebabkan mahasiswa Teknik Informatika kesulitan belajar mata kuliah Aljabar Linier diantaranya, yaitu kurangnya minat belajar mahasiswa pada materi Aljabar Linier, kemampuan dasar Aljabar Linier yang rendah, dan kurangnya kemampuan dalam mengaplikasikan konsep Aljabar Linier dalam menyelesaikan soal. Selain faktor yang telah disebutkan, terdapat kesalahan yang muncul ketika menyelesaikan soal Aljabar Linier. Berikut indikator kesalahan mahasiswa Teknik Informatika dalam menyelesaikan soal Aljabar yang juga menyebabkan adanya kesulitan belajar 
mahasiswa dalam mata kuliah Aljabar Linier.

(1) Kurang teliti dalam memahami persoalan Aljabar Linier

(2) Kurang teliti dalam pengoperasian bilangan aljabar maupun bilangan bulat

(3) Kurang mampu dalam konsep operasi bilangan elementer, dan

(4) Kurangnya kemampuan logika mahasiswa dalam menyusun cara penyelesaian soal.

Saran

Dari hasil penelitian ini, peneliti memberikan beberapa saran sebagai berikut.

(1) Peneliti selanjutnya dapat memberikan solusi untuk mengurangi kesulitan mahasiswa Teknik Informatika dalam menempuh mata kuliah Aljabar Linier.

(2) Pendidik perlu mengetahui penyebab kesulitan mahasiswa Teknik Informatika mengenai Aljabar Linier sehingga mahasiswa tidak mengulangi kesalahan ketika menyelesaikan soal.

(3) Pendidik perlu memberikan motivasi dalam memberikan materi mata kuliah sehingga menumbuhkan minat belajar mahasiswa Teknik Informatika pada mata kuliah Aljabar Linier.

\section{DAFTAR PUSTAKA}

Arikunto, Suharsimi. 2010. Prosedur Penelitian Suatu Pendekatan Praktik. Yogyakarta: PT Rineka Cipta

Djafar, D., Wahyuni, E. I., \& Reziyustika, L. 2019. Analisis Kesulitan Belajar Mahasiswa Pada Mata Kuliah Aljabar
Linier. Jurnal PRINSIP Pendidikan Matematika, 2(1), 29-33.

Ferryansyah, Widyawati, E., \& Rahayu, S.W. 2018. The analysis of students' difficulty in learning linear algebra. Journal of Physics: Conf. Series 1028 (2018) 012152.

Pramesti, T. I., \& Retnawati, H. 2019. Difficulties in learning algebra: An analysis of students' errors. Journal of Physics: Conference Series1320 (2019) 012061.

Setyaningrum, R. S., Syamsuri, \& Setiani, Yani. 2020. Analyzying Students' Learning Difficulties in Algebra. Jurnal Matematika dan Pembelajaran, 8(1), 19-34.

Sugiarti, L., \& Retnawati, H. 2019. Analysis of student difficulties on algebra problem solving in junior high school. Journal of Physics: Conf. Series 1320 (2019) 012103.

Sukmadinata, Nana Syaodih. 2009. Metode Penelitian Pendidikan. Bandung: Remaja Rosdakarya.

Wasito, N., \& Kurniawan, F. A. 2018. Analisis Penyebab Kesulitan Belajar Mahasiswa Dalam Pembelajaran Konstruktivis Mata Kuliah Aljabar Linier. Jurnal Pendidikan Matematika Indonesia, 3(2), 47-51.

Wati, S., Fitriana, L., \& Mardiyana, M. 2018. Technological pedagogical content knowledge of junior high school mathematics teachers in teaching linear equation. Journal of Physics: Conference Series, 1008(1). https://doi.org/10.1088/17426596/1008/1/012067. 
Wijaya, T. T., Hidayat, W., \& Zhou, Y. 2020.

Development of Interactive Learning Video on Linear Program. Universal
Journal of Educational Research, 8(12A), 7530-7538. https://doi.org/10.13189/ujer.2020.082 537. 